\title{
BRAVE NEW WORDS: LABOUR, THE COURTS AND THE CANADIAN CHARTER OF RIGHTS AND FREEDOMS
}

\section{Judy Fudge*}

In Health Services and Support - Facilities Subsector Bargaining Association v. British Columbia, [2007] 2 S.C.R. 391, the Supreme Court of Canada overturned precedent and concluded "that the grounds advanced in the earlier decisions for the exclusion of collective bargaining from the Charter's protection of freedom of association do not withstand principled scrutiny and should be rejected" (at para. 22). The author explores the Supreme Court of Canada's change of heart and what this change implies, not only for constitutional doctrine, but also for what the Court understands about the governance of the postFordist world of work. She situates the Court's reasoning in a few key cases dealing with labour's distinctive rights - to bargain collectively and to strike - in the social context that both shapes the legal discourse about labour rights and influences organized labour's power. She considers the paradox of the Supreme Court's embrace of Fordist labour rights in a post-Fordist economy, and suggests a modest, though important, role that the Court could play in fostering social justice in the brave new world of work.

Dans l'arrêt Health Services and Support - Facilities Subsector Bargaining Association c. Colombie-Britannique [2007] 2 R.C.S. 391, la Cour Suprême du Canada a invalidé un précédent et a conclu que "les motifs avancés dans les arrêts précédents pour exclure les négociations collectives de la protection accordée par la Charte à la liberté d'association ne résistent pas à un examen fondé sur les principes pertinents et quils devraient être écartés» (au para. 22). L'auteure explore le revirement de la Cour Suprême du Canada et ce qu'implique ce changement, non seulement pour la doctrine constitutionnelle, mais aussi pour ce que la Cour comprend au sujet de la façon de gouverner dans le monde post-Fordiste du travail. Elle situe le raisonnement de la Cour dans quelques cas-clés traitant des droits distinctifs des travailleurs - la négociation collective et la grève - dans le contexte social qui à la fois détermine la forme du discours juridique au sujet des droits des travailleurs et influence le pouvoir du mouvement syndical. Elle considère le paradoxe que la Cour Suprême

Professor and Lansdowne Chair and member of the Inter-University Research Centre for Globalization and Work [CRIMT]. This paper was initially presented as the Windsor Access to Justice Lecture, March 2, 2009. I would like to thank the Editorial Board of the Windsor Yearbook Access to Justice, and particularly Bill Conklin, for extending me the invitation to come and visit the Windsor Law School and the Social Sciences and Research Council for funding the research upon which this paper is based. I owe a great debt of gratitude to Harry Glasbeek, with whom I have discussed the idea of constitutionalizing labour rights over many years. 
épouse des droits des travailleurs Fordistes dans une économie post-Fordiste, et suggère un rôle modeste, mais important, que pourrait jouer la Cour pour favoriser la justice sociale dans le nouveau monde prometteur du travail.

As the history of the past century has demonstrated, the power of organized labour, the necessary co-partner of capital, must be available to redress the balance of what is called social justice: the just protection of all interests in an activity which the social order approves and encourages. ${ }^{1}$

Justice Ivan Rand 1946

\section{INTRODUCTION}

Three moments in the history of Windsor, which is located in Canada's badly rusted industrial heartland, exemplify the post-war fortunes of the labour movement. It is helpful to historicize these moments - to recontextualize and re-interpret them in light of categories and problems not available to the participants - so that we can more distinctly see the arc of the labour movement and labour rights over the last sixty years. This trajectory is crucial for understanding both the discourse of, and jurisprudence on, labour rights since the Canadian Charter of Rights was entrenched in 1982. ${ }^{2}$ What Charles Tilly claimed about politics -"every significant political phenomenon lives in history and requires historically grounded analysis for its explanation" - is also true about law. ${ }^{3}$

In 1944, unions had obtained collective bargaining legislation, which placed an obligation on employers to bargain exclusively with the union representing a majority of the employees at a specific workplace. ${ }^{4}$ However, they had good reason to fear a reprise of the government and employer assault that occurred at the end of World War I, and thus they wanted a form of union security arrangement that would strengthen their presence in the workplace and provide them with financial stability. These arrangements took the form of clauses in collective agreements whereby employers agreed to various forms of compulsory union membership for their employees and deducted and transmitted employee dues directly to the union. In Canada, few industrial unions had managed to obtain any form of security, whereas in the US maintenance of membership and checkoff clauses in collective agreements were the norm. The refusal of employers to enter into collective agreements containing a union security provision was the crux of organized labour's complaint that the duty of good faith imposed by the new collective bargaining regime did not ensure the conclusion of a collective

1 Justice Ivan Rand, Ford Motor Company of Canada and U.A.W., 46 C.L.L.LC. 18,001 at 160. [Ford Motor]

2 Part 1 of the Constitution Act, 1982 being Sch. B to the Canada Act 1982 (UK), 1982, c.11.

3 Charles Tilly, "Why and How History Matters" in Robert E. Goodin and Charles Tilly, eds., Oxford Handbook of Contextual Political Analysis (Oxford: Oxford University Press, 2006) at 20.

4 This account is drawn from Judy Fudge and Eric Tucker, Labour Before the Law (Toronto: Oxford and University of Toronto Press, 2001, 2004) at chapters 10 and 11. 
agreement. Because the federal government refused to impose them, union security agreements in Canada would have to be won in major strikes.

The showdown over union security occurred when Local 200 of the United Autoworkers [UAW] struck Ford's Windsor operations in 1946. The Local engaged in mass picketing, and community support for the strike was strong. Attempts by three levels of government to deploy force to break the impasse backfired as the threat of force catalyzed sympathy for the strikers. In order to settle the strike, the federal government proposed binding arbitration and appointed Justice Ivan Rand to do the job. ${ }^{5}$ The Ford strike established both the basis for the entente between industrial unions and large employers over the issue of union security and the occasion for the Canadian state to establish the parameters of legitimate coercion within the labour regime of post-war Canada.

Rand's analysis of what collective bargaining both assumed and entailed quickly became conventional wisdom and established industrial pluralism as official labour relations policy in Canada. His starting point was that "[a]ny modification of relations between the parties here concerned must be made within the framework of a society whose economic life has private enterprise as its dynamic." His second premise was that the federal government had accepted the need to protect workers' right to form unions and engage in collective bargaining. According to Rand, unions needed to be strong in order to "secure industrial civilization within a framework of labour-employer constitutional law based on rational economic and social doctrine." In order to strengthen unions, and to ensure that they behaved responsibly, Rand ordered that Ford agree to a compulsory dues check-off to apply to every employee covered by the collective agreement regardless of union membership, which the union would have to forfeit if it failed either to hold secret strike ballots or to repudiate strikes during the term of a collective agreement. As the quotation that begins this paper illustrates, Rand understood that strong unions were necessary for social justice in a capitalist society, and his eponymous union security formula became a distinctive feature of the Canadian regime of industrial pluralism.

The Ford strike established both the basis for the entente between industrial unions and large employers over the issue of union security and the occasion for the Canadian state to establish the parameters of legitimate coercion within the regime of industrial pluralism. Moreover, Fordism came to symbolize the post-war economic settlement. In the first world, nation states used Keynesian demand-management techniques and social welfare policies to support the standard employment relationship - a full-time, on-going job that was unionized and that came with security and benefits - that was anchored to large vertically integrated firms. The trade-off of productivity gains for wage increases in key economic sectors (manufacturing, transportation, and resources), which were

5 William Kaplan, Canadian Maverick: The Life and Times of Ivan Rand (Toronto: Osgoode, 2009) at c. 5 .

6 Ford Motor, supra note 1 at 159.

7 Ibid. at 160. The Alberta Labour Relations Board declared that the failure of to provide unions with a right to a Rand formula (compulsory dues check-off) in the collective bargaining legislation violated the freedom of association in the Charter, U.F.C. W. Union Local, No. 401 and Old Dutch Food, Alberta Labour Relations Board, Files no.: GE-05611, 9 November 2009. 
secured through collective agreements, was the basis of the industrial relations system. Fordism enabled men to earn a breadwinner wage and expected women to stay home and take care of the children. ${ }^{8}$

The second moment was the early 1980s, when the industrial pluralist labour regime reached its pinnacle, and, as we now know in hindsight, its breaking point. Unionization peaked at 40 per cent in 1982, and it has declined slowly ever since. ${ }^{9}$ In 1982, governments across the country imposed wage controls on their employees in an effort to wring inflation out of the economy. ${ }^{10}$ The central bank embarked on a high-interest rate policy, and across the country all levels of governments began to privatize government industries and services as well to deregulate economic activities. Unemployment was 11 per cent in 1982, and the auto industry reeled as the Canadian economy and firms began the painful process of restructuring. ${ }^{11}$

The third moment was the financial crisis of 2008. Fordism, by which I am referring to the broader political and economic configuration, is on its last leg. China now builds and sells more cars than does the United States. ${ }^{12}$ General Motors and Chrysler, which was owned by Daimler, staved off bankruptcy by obtaining massive government bailouts, and, along with Ford, they obtained huge concessions from the Canadian Autoworkers Union, one of the few remaining industrial unions. Autoworkers' pensions and benefits are increasingly insecure, and thousands of autoworkers in the assembly and parts sectors have been laid off. Those who remain will be working at lower wages and with fewer and less generous benefits. ${ }^{13}$ Union density in the private sector is down to 16 per cent, wages have declined, jobs have become more precarious, and the share of the gross domestic product going to labour has shrunk to a proportion not seen since before World War II. ${ }^{14}$

8 Anne Forrest, "Securing the Male Breadwinner: A Feminist Interpretation of PC 1003" in Cy Gonick, Paul Phillips, and Jesse Vorst, eds., Labour Gains, Labour Pains: Fifty Years of PC 1003 (Winnipeg: Fernwood, 1995)139; Jane Ursel, Private Lives and Public Policy: 100 Years of State Intervention in the Family (Toronto: Women's Press, 1992) at 179.

9 René Morissette, Grant Schellenberg \& Anick Johnson, "Diverging Trends in Unionization" (2005) 6:4 Perspectives on Labour and Income 5 at 5; "Unionization" (2007) 7:8 Perspectives on Labour and Income 5 at 5; "Unionization" (2008) 9:8 Perspectives on Labour and Income 17.

10 Leo Panitch \& Donald Swartz, From Consent to Coercion: The Assault on Trade Union Freedoms, 3rd ed. (Aurora: Garamond Press, 2003).

11 Ann Porter, Gendered States: Women, Unemployment Insurance, and the Political Economy of the Welfare State in Canada, 1945-1997 (Toronto: University of Toronto Press, 2003) at 181.

12 Greg Keenan, "China outruns U.S. in vehicle sales" The Globe and Mail (4 February 2009) B1, B7.

13 Ben Austen, "End of the Road: After Detroit the end of an American Dream" Harper's Magazine (August 2009) 26; Peter B. Boyer, "The Road Ahead: Smyrna, Tennessee vs. Detroit" (April 27, 2009) The New Yorker 24; Greg Keenan, "Chrysler Vows to Carry On” The Globe and Mail (12 January 2009) B11; Greg Keenan, Karen Howlett, and Shawn McCarthy, "Chrysler cuts 1,200 as auto crisis depends" The Globe and Mail (5 March 2009) B1; Shawn McCarthy, Greg Keenan and Karen Howlett, "Taxpayers to fork out billions for GM pension aid" The Globe and Mail (23 May 2009) A1,A4; Greg Keenan, "GM strikes cost-cutting deal to meet bailout demands" The Globe and Mail (9 March 2010) A1, A2.

14 Judy Fudge, "The New Workplace: Surveying the Landscape" (2009) 33(1) Man. L.J., 121; Michael Lynk, "Labour Law and the New Inequality" (2009) 59 U.N.B.L.J. 14. 
Canadian unions' attempts to secure labour rights a legal status as constitutionally protected and fundamental are the focus of my examination of the relationship between law and social justice. What I am interested in are the rights and freedoms of people to control and to determine the terms and conditions of the sale and deployment of their labour. Unions, as frail and imperfect as they are, promote distributive justice in the workplace, and high union density is associated with greater substantive equality in society. ${ }^{15} \mathrm{I}$ am particularly interested in how the Supreme Court of Canada treats what are labour's distinctive rights - the rights to bargain collectively and to strike. As a student of Canadian labour law history, I predicted that the courts would not be receptive to unions' arguments that the rights to bargain collectively and to strike were protected under the freedom of association enshrined in the Charter. ${ }^{16}$ Initially, I was correct. In 1987 the majority of the Supreme Court dismissed collective bargaining as, at best, a mere legislative, and not a fundamental constitutional right, and, at worse, an activity akin to playing golf, as Justice McIntyre so disparagingly portrayed it. ${ }^{17}$ Twenty years later, in 2007, a majority of the Supreme Court of Canada proved me wrong. In the British Columbia Health Services Sector case the majority of the Court overturned the decisions that came to be known as the Labour Trilogy. ${ }^{18}$ They concluded "that the grounds advanced in the earlier decisions for the exclusion of collective bargaining from the Charter's protection of freedom of association do not withstand principled scrutiny and should be rejected." 19

This is a somewhat remarkable decision for a Court to make. The judiciary holds out that it makes decisions based on a reasoning process that looks backwards for principle and only moulds those principles to the extent necessary to allow for manifest changes in social circumstance. Changes are incremental and defensible as dependent on reason, rather than power, and as reflecting acknowledged changes, not desired or anticipated ones. How could an institution that claims that its legitimacy springs from these kinds of processes make such a u-turn? What was the radical change in circumstance the judges perceived to warrant such a reversal? What was the motivation for this changed reading of the Charter?

I want to explore the Supreme Court of Canada's change of heart and what this change implies, not for constitutional doctrine, but rather for what the Court understands about the governance of the post-Fordist world of work. The

15 Lynk, ibid. at 29; Lane Kenworthy and Jonas Pontusson, "Inequality and the Politics of Redistribution in Affluent Countries," (2005) 3(3) Perspectives on Politics 449.

16 Judy Fudge, "Labour, The New Constitution and Old Style Liberalism" (1988) 13(2) Queen's L.J. 61.

17 The following cases came to be known as the Labour Trilogy: Reference Re Public Service Employee Relations Act (Alberta), [1987] 1 S.C.R. 313, 38 D.L.R. (4th) 161 [Alberta Reference cited to S.C.R.]; PSAC v. Canada, [1987] 1 S.C.R. 424, 38 D.L.R. (4th) 249 [PSAC cited to S.C.R.]; RWDSU v. Saskatchewan, [1987] 1 S.C.R. 460, 38 D.L.R. (4th) 277 [RWDSU]. For McIntryre J.'s comment see Alberta Reference, at 404.

18 Health Services and Support - Facilities Subsector Bargaining Association v. British Columbia, [2007] 2 S.C.R. 391 [Health Services].

19 Ibid. at para. 22. 
Court, being a court, did not directly speak to what motivated it. Its collective state of mind must be gleaned from its rhetoric. The Court contended that its decision was justified by its newly developed sense of legal history and by the fact that its startling decision dovetailed with, and directly, supported, values that inhered in the Charter and in the legal, political, and social values of Canada.

I will place the Court's reasoning in a few key cases dealing with labour's distinctive rights - to bargain collectively and to strike - in the economic and political context that both shapes the discourse about labour rights and influences organized labour power. The decisions I have chosen to discuss coincide with the second and third moments in labour movement's history, and they illustrate how both unions and courts have turned to human rights discourse to articulate labour rights. In the end, the holding in the Health Services Sector case asks the public to accept that the Court was reflecting an entente that was forged in the originating moment of Fordism. I will consider the paradox of Court's embrace of Fordist labour rights in a post-Fordist economy, and suggest a modest, though, important role that the Court could play in fostering social justice in the brave new world of work.

\section{THE LABOUR TRILOGY AND NEO-LIBERALISM}

Despite the fact that organized labour in Canada was deeply ambivalent about the significance of entrenching rights specific to labour in the Canadian Charter, unions had early cause to invoke the freedom of association. The year the Charter of Rights and Freedoms was entrenched, 1982, the federal government and six provincial counterparts imposed wage controls on public sector employees. ${ }^{20}$ Unions tried to use the Charter's protection of freedom of association defensively to resist the first onslaught of neo-liberalism and to protect basic features of Canada's collective bargaining regime in the public sector. Unions challenged the federal public sector wage controls that prohibited them from striking to resolve disputes during negotiations and substituted compulsory arbitration. ${ }^{21}$ They also challenged public sector collective bargaining legislation in Alberta that prohibited all public sector workers from striking, ${ }^{22}$ and back-to-work legislation that ended an otherwise lawful strike at a dairy cooperative in Saskatchewan. $^{23}$

Unlike the women's movement, which established a central organization, the Women's Legal Education and Action Fund, to engage in test-case litigation in order to shape the Charter's equality jurisprudence, organized labour did not develop a co-coordinated strategy about which cases to push forward and the kinds of arguments to make in order to shape the freedom of association jurisprudence. Although the Canadian Labour Congress, the central union federation to which most unions in Canada (except those based in Quebec) belong, intervened in many cases, the lack of a co-ordinated litigation strategy by the labour

20 Panitch and Swartz, supra note 10.

21 Alberta Reference, supra note 17.

22 PSAC, supra note 17.

$23 R W D S U$, supra note 17. 
movement in Canada reflects the competitive nature of unions in Canada and the United States. Competitive unionism is a key feature of industrial pluralism, which tends to support free, but weak, trade unions that are institutionalized at the level of the workplace and not at the sectoral or national level. ${ }^{24}$

The relationship between the courts and organized labour has been particularly fraught. ${ }^{25}$ The common law's emphasis on individual civil rights justified the court's historic hostility to workers' collective rights. Workers' freedom to bargain collectively and to associate in unions for that purpose were easily trumped by employers' freedom of contract and property rights. Legislation was necessary to transform the freedom to bargain collectively into a right. In 1944 the federal government enacted wartime regulations that institutionalized Wagner-style collective bargaining. If a majority of workers at a workplace joined and supported a trade union, their employer was required to bargain exclusively with that union, and if negotiations broke down, the parties were permitted to resort to industrial sanctions - strikes and lockouts. In Canada, like the United States, the right to bargain collectively was institutionalized as industrial pluralism.

In an industrial pluralist regime, the role of the state is to set up a procedure in which trade unions and employers negotiate collective agreements. The relationship between the parties is regarded as essentially conflictual, bargaining predominantly takes place at the workplace level, and both the process and the relationships are regarded as economic and not political. By contrast, under a corporatist regime, the state takes a more active role, bargaining takes place at an industrial or national level, and the bargaining process, as well as the relationships, are regarded as both economic and political. ${ }^{26}$

As the system of industrial pluralism matured, labour boards, which had been established to administer the regime, elaborated the employer's duty to bargain in good faith with the union representing a majority of its employees. They also gave content to unfair labour practices in the context of employers' attempts to undermine independent trade unions and collective bargaining by, among other things, intimidating employees. Throughout the formative post-war period, the judges exhibited a stubborn adherence to old case law that protected individual contract-making and employer's property rights. Courts overturned labour board decisions and restricted labour board powers. ${ }^{27}$

The courts' adherence to the common law and their lack of sympathy for the new regulatory regime drew a storm of disparaging academic opinion from "modern" commentators who supported industrial pluralism. ${ }^{28}$ The burden of

24 Teri L. Caraway, "Freedom of Association: Battering Ram or Trojan Horse?” (2006) 13(2) Review of International Political Economy 210.

25 A.W.R. Carrothers referred to the "see-saw vendetta between the courts and the legislatures" in Collective Bargaining Law in Canada (Toronto: Butterworths, 1965) at 57.

26 Guy Mundlak, Fading Corporatism: Israel's Labor Law and Industrial Relations in Transition (Ithaca: ILR Press, 2007) at 13-15, 227-40.

27 Paul Weiler, Reconcilable Differences: New Directions in Canadian Labour Law (Toronto: Carswell, 1980).

28 Ibid. Also see, David Beatty, "Secondary Boycotts: A Functional Analysis" (1974), 52 Can. Bar Rev. 388; Geoffrey England, "Some Thoughts on Secondary Picketing” in Geoffrey England and George Lerner, eds., Essays in Collective Bargaining and Industrial Democracy (Toronto: 
the academic literature was that the judiciary was an institution out of time and place. Its commitment to individualism and its formalistic reasoning was incapable of dealing with the polycentric issues thrown up by a collectivist scheme that was to thrive on continuing and dynamic relationships. This criticism led to a consensus that it was necessary to wall off collective bargaining from judicial intervention. In an attempt to render collective bargaining as much of a self-standing regime as possible, the perfection of remedial powers for both private arbitrators and public labour relations boards was engineered. ${ }^{29}$ Efforts were made to prevent courts from reviewing these specialized dispute-settling tribunals by enacting stringent privative clauses. ${ }^{30}$ The legislative challenge was to impede the application of the common law doctrines to the modern regulatory scheme.

The message sent to the courts by elected governments and their policy-makers ought to have been clear: their judicial principles and their methodology belonged to an era when the political economy was different, when the demands it made of law were incompatible with the requirements of the new political circumstances that had spawned Keynesian welfarism and a new legitimacy for collective worker actions. But, the judges did not get the message or, at least, did not accept its finality. They finessed their way around privative clauses; they remained faithful to private property and contract dogma whenever they were given the opportunity to intervene in collective relations. ${ }^{31}$ They did so even when some of the judiciary's own luminaries indicated that this was unwarranted. In particular, Bora Laskin used the prestige of the Supreme Court of Canada to proclaim the autonomy and integrity of collective bargaining from the common law. ${ }^{32}$ Academics continued to criticize the formalism of, and commitment to, the common law by the judges, who paid little heed to their complaints.

Thus, it was not surprising when the Supreme Court of Canada released at the same time, in 1987, three cases, which came to be known as the Labour Trilogy, in which the majority of the Court rejected the argument that freedom of association includes labour rights. According to Justice LeDain, who wrote for the majority:

CCH Canadian, 1983); S.A. Tacon, Tort Liability in a Collective Bargaining Regime (Toronto: Butterworths, 1980).

29 Laskin, as an arbitrator, whose intellectual weight came to be enormous in this field, set the tone for the enhanced scope of arbitral decision-making in order to effectuate the principles of collective bargaining in Re Polymer (1958), 10 L.A.C. 31, affd., [1962] S.C.R. 338 [sub nom. Imbleau v. Laskin]. As to the enlargement of the remedial powers of labour relations boards, these were the immediate outcomes of the Woods Task Force. The Report of the Task Force on Labour Relations (H.D. Woods: Chair) (Ottawa: Queen's Printer, 1969).

30 The most far-reaching attempt was made in British Columbia: Trade-unions Act ${ }_{2}$ R.S.B.C. 1960, c. 384, s.3; later the Labour Relations Code, R.S.B.C. 1979, c.44.

31 See the ensuing lament by H.W. Arthurs, “The Dullest Bill': Reflections on the Labour Code of British Columbia” (1974), 9 U.B.C. L. Rev. 280.

32 In McGavin Toastmaster Ltd. v. Ainscough, (1975), 54 D.L.R. (3d) 1, Laskin, C.J., made the same argument he had made as an arbitrator in U.A.W., Local 458 v. Cockshutt Farm Equipment (1959), L.A.C. 324, and as an academic in "Collective Bargaining and Individual Rights" (1963), 6 Can. Bar Rev. 278. 
[t]he rights for which constitutional protection are sought - the modern rights to bargain collectively and to strike, involving correlative duties or obligations resting on an employer - are not fundamental rights or freedoms. They are the creation of legislation, involving a balance of competing interests in a field which has been recognized by the courts as requiring a specialized expertise. ${ }^{33}$

In what subsequently became the most influential set of reasons, Justice McIntyre limited freedom of association to the protection of all activities pursued in association with others that a person could lawfully pursue as an individual. ${ }^{34}$ Since collective bargaining and striking are inherently collective, these activities simply cannot be performed on an individual basis, and, according to Justice McIntyre, they did not deserve constitutional protection. According to him, "[i]f Charter protection is given to an association for its lawful acts and objects, then the Charter-protected rights of the association would exceed those of the individual merely by virtue of the fact of association." ${ }^{35} \mathrm{He}$ invoked the examples of gun and golf clubs to demonstrate how unacceptable it would be to protect the objects and activities of an association. ${ }^{36} \mathrm{He}$ also agreed with Le Dain J. that courts should defer to legislatures when it came to labour legislation since labour relations was a matter of politics and economics. ${ }^{37}$

The problem with the deference rationale is that the Supreme Court only seems to appreciate the need for deference to the institutions of industrial pluralism at the very moment that they were under legislative attack. Furthermore, McIntrye J.'s simple analogy between gun and golf clubs and trade unions is inappropriate. The crucial issue is not whether there is an individual analogue (such as an individual employee's quitting) to a strike, ${ }^{38}$ but whether it is accurate to equate qualitatively different kinds of association for the purpose of guaranteeing Charter rights. It is the objects of the association and the values that the association promotes, as well as the history of how the law has treated the association, that are important in determining the scope of Charter-protected rights.

However, a strong contrapuntal theme in the Labour Trilogy was Chief Justice Dickson's dissent, in which he emphasized the distinctive nature of trade unions and labour rights, which is their collective dimension. ${ }^{39}$ He referred to the International Labour Organization (ILO) and its jurisprudence on the freedom of association as a source for the meaning of the Canadian guarantee. According

33 Alberta Reference, supra note 17 at 391.

34 Ibid. at 407.

35 Ibid. at 404.

36 Ibid.

37 Ibid. at 414.

38 See David Beatty \& Steven Kennett, "Striking Back: Fighting Words, Social Protest and Political Participation in Free and Democratic Societies" (1988) 67 Can. Bar Rev. 573 at 589.

39 Alberta Reference, supra note 17 at 353. Wilson J. agreed with Dickson C.J.'s characterization of the scope of the freedom of association in the Labour Trilogy, although she departed from him over the s. 1 analysis. 
to him, "[f]reedom of association is the cornerstone of modern labour relations. Historically, workers have combined to overcome the inherent inequalities of bargaining power in the employment relationship and to protect themselves from unfair, unsafe, or exploitative working conditions." ${ }^{20} \mathrm{He}$ went on to state that "[i]f freedom of association only protects the joining together of persons for common purposes, but not the pursuit of the very activities for which the association was formed, then the freedom is indeed legalistic, ungenerous, indeed vapid." ${ }^{41} \mathrm{He}$ concluded that collective bargaining and striking were essential if unions were to be able to attain their objects and, thus, were included under the freedom of association protected in the Charter.

Two subsequent cases, the first in 1990 and the second in 1999, affirmed what Chief Justice Dickson considered to be a vapid interpretation of freedom of association, one that included only the right to join a trade union and not the rights to bargain collectively or to strike. ${ }^{42}$ Union leaders' responses to these decisions varied. ${ }^{43}$ Many distinguished between the fundamental ethical and democratic rights to bargain and to strike, and the legal recognition of those rights. Some noted the historical antipathy of the courts to organized labour and labour's distinctive rights. Others lamented the legal defeat. Overall, by the end of the 1980s, most unions agreed with Nancy Riche, a vice-president of the Canadian Labour Congress, who said:

As much as we are not crazy about a lot of politicians who are in power across the country, we would still take our chances with the political leaders and the lobby effort and the pressure we bring to bear on getting change as it affects the trade union movement, as opposed to leaving it to the courts. ${ }^{44}$

40 Ibid. at 334.

41 Ibid. at 362-3.

42 In Professional Institute of the Public Service of Canada (PIPSC) $v$. Northwest Territories (Commissioner),[1990] 2 S.C.R. 367, 72 D.L.R. (4th) 1 [PIPSC v. Northwest Territories cited to S.C.R.]. The Court split four to three, with five judges writing reasons. Sopinka J. wrote substantive reasons dismissing the appeal while Dickson C.J., La Forest J. and L'HeureuxDubé J. each wrote their own reasons, agreeing in the result with Sopinka J., who limited the constitutional guarantee of freedom of association to that of simply forming an association. In the 1999 case of Delisle v. Canada (Deputy Attorney General), [1999] 2 S.C.R. 989, 176 D.L.R. (4th) 513 [Delisle], the Supreme Court issued another narrow interpretation of freedom of association in the labour relations context. Writing for the majority (four of the seven judges), Bastarache J. held that only the establishment of an independent employee association and the exercise in association of the lawful rights of its members are protected under the freedom of association in the Charter (Ibid. at para. 28). He also stated that the protection of fundamental freedoms would not generally impose a positive obligation of protection or inclusion on the government. Delisle at para. 33. In her concurring reasons L'Heureux-Dubé J. indicated that there might be a positive obligation to provide legislative protection against unfair labour practices or some form of official recognition under labour legislation because of the inherent vulnerability of employees to management: ibid.

43 Larry Savage, "Organized Labour and the Canadian Charter of Rights and Freedoms" (2007) 36 Sup. Ct. L. Rev. 175.

44 Larry Savage, "Workers Rights as Human Rights: Organized Labor and Rights Discourse in Canada” (2009) 34(1) Labor Studies Journal 8 at 11. 
At the same time that unions reaffirmed their preference for the political process to vindicate their rights and legitimacy, legislatures began to roll back the institutions of industrial pluralism, first in the name of fiscal responsibility and, then, in the name of ideological purity. ${ }^{45}$ When the Supreme Court of Canada released the Labour Trilogy in 1987, Canada had fully embraced neo-liberalism. The US-Canada Free Trade deal was ratified in 1988, and the North American deal, which was concluded in 1993, was in the offing. Public sector workers were targeted for restraint throughout the 1990s. Privatization and deregulation were intended to unleash competitive market forces. These prescriptions became "so dominant at the level of global economic policy" they "constitute, in John Stuart Mill's phrase, 'the deep slumber of decided opinion'." 46 The forces of globalization accelerated the restructuring of the economy, unionization rates began a slow decline, and earnings inequality increased. ${ }^{47}$

While the Supreme Court of Canada's decision that labour rights were not fundamental constitutional rights did not cause neo-liberalism, they coincided with, and reinforced, it. By characterizing collective bargaining as the result of political and economic bargaining and not a fundamental right, the Court declined the opportunity to impose any constraints on the ability of governments to revert to the common law default of individual contracting. Governments across the country were free to retrench key elements of industrial pluralism without any fear of constitutional restriction. Legal recognition is profoundly significant in explaining the power of rights claims. As Michael McCann points out, "the symbolic manifestation of law, as a source of moral rights and threat of potential outside intervention, invests rights discourse with its most fundamental social power." 48

The Supreme Court of Canada's decisions that labour rights were not fundamental constitutional rights also coincided with organized labour's loss of economic and political power and confirmed its loss of social legitimacy. Since the early 1990s unions have moved from crisis to crisis. Governments across the country have made it more difficult to unionize workers in the private sector by changing labour laws, and have interfered with collective bargaining in the public sector. ${ }^{49}$ The economy has radically altered, and firms and work processes have been restructured. Once powerful private sector unions are no longer strong.

Neo-liberalism discredited the welfare state and the new economy has accelerated the breakdown of the traditional firm, which was the basis upon which unions were organized in developed non-socialist countries after World War II.

45 Panitch and Swartz, supra note 10; Judy Fudge and Eric Tucker, "Pluralism or Fragmentation? The Twentieth-Century Employment Law Regime in Canada" (2000) 46 Labour 251; Mark Thompson, Joseph B. Rose, \& Anthony E. Smith, eds., Beyond the Divide: Regional Dimensions of Industrial Relations (Montreal and Kingston: McGill Queen's University Press, 2003).

46 Robert Wade, "Financial Regime Change" (2008) 54 New Left Review 53.

47 Fudge, supra note 14; Lynk, supra note 14.

48 Michael McCann, "Law and Social Movements: Contemporary Perspectives" (2006) 2 Annual Review of Law and Social Sciences 1 at 30.

49 Panitch and Swartz, supra note 10; Fudge and Tucker, supra note 45; Thompson, Rose \& Smith, supra note 45. 
The construction and expansion of global markets in finance and trade has put pressure on unions and placed constraints on nation states. This transformation in political ideology and economic reality has had a profound impact on the traditional supports for labour rights. Laws that protected and promoted trade unions have been undermined as the economy and the structure of enterprises have changed or have been refashioned to promote competition via individual contracting.

\section{LABOUR RIGHTS AS HUMAN RIGHTS}

Although neo-liberal globalism may have "curtailed the possibility of labour to sustain and be a conduit for the enjoyment of the rights of citizenship even in the core countries," ${ }^{50}$ it has spawned within itself an extensive oppositional culture. ${ }^{51}$ The rise of opposition cast in terms of violations of human rights has been spectacular since the 1980s. However, as David Harvey, the social geographer, has remarked, this form of opposition tends to accept many of the basic assumptions of neo-liberalism and to focus on its internal contradictions. $\mathrm{Hu}-$ man rights claims have a number of common elements that elevate them to a fundamental status. They are the rights of individuals; they are universal; they are inalienable; they are indivisible, and they are unequivocal. The goal of many human rights organizations is to have human rights legally recognized, either by the appropriate court or international institution. Thus, human rights tend to map strongly on to civil and political rights, although one of the goals of the human rights movement is to expand the suit of fundamental rights to include social and economic ones. ${ }^{52}$ The shift by unions to characterize labour rights as human rights is part of the broader countermovement to neo-liberalism. With the decline of the traditional vehicles for labour rights, such as the welfare state and collective bargaining, "legal and constitutional mechanisms are increasingly being used to assert social claims." ${ }^{53}$ Law's prominence is a distinctive feature of the contemporary discourse of labour rights.

The turn to the law in order to vindicate labour's distinctive rights also exemplifies organized labour's contemporary weakness. Juridification, as Guy Mundlak explains, is a process of "establishing mandatory legal norms that substitute for extra-legal regulation of social and economic relationships." ${ }_{44}$ Moreover, "it is not merely a matter of legal imperialism but also a process of compensation for the decline of extralegal norms." ${ }^{55}$ Labour rights were institutionalized through semi-autonomous forms of self-regulation that both had a legislative base and depended for their survival on limiting the intervention of the courts.

50 Boaventura de Sousa Santos, Toward a New Common Sense: Law, Science and Politics in the Paradigmatic Transition, $2^{\text {nd }}$ ed. (London: Butterworths, 2002) at 480.

51 David Harvey, A Brief History of Neo-liberalism (Oxford: Oxford University Press, 2005) at 50.

52 Ibid. at 57; Judy Fudge, "The New Discourse of Labour Rights: From Social to Fundamental Rights?” (2007) 29(1) Comparative Labour Law and Policy Journal 29.

53 Simon Deakin, "Social Rights in a Globalized Economy" in Philip Alston, ed., Labour Rights as Human Rights (Oxford: Oxford University Press, 2005) 25 at 52.

54 Mundlak, supra note 26 at 154.

55 Ibid. 
Now unions are turning to the courts in order to defend the quasi-autonomous institution of collective bargaining. The campaign to have labour rights recognized as fundamental human rights has two components - the international and the domestic - and these components are related. The first component is best exemplified by unions' attempts to seek vindication for labour rights at the International Labour Organization. Canadian unions have been aggressive in using this tactic, and public sectors unions, in general, and the National Union of Public and Government Employees, in particular, have spearheaded it. ${ }^{56}$ Since the early 1980s, Canadian unions have outpaced all other national labour movements in lodging complaints with the International Labour Organization that governments across the country have violated the freedom of association. Of the 76 cases decided by the ILO's Committee on Freedom of Association between 1982 and 2008, the Committee found Canada in violation in 71 complaints. Of the one hundred and eighty-one member states of the ILO, Canada has had the dubious achievement of having one of the highest numbers of successful complaints brought against it for violating workers' rights to freedom of association and collective bargaining. ${ }^{57}$

Moreover, Canadian unions' attempts to vindicate their rights as international rights recognized by the ILO coincided with a characterization of labour rights at the international level. The ILO's 1998 Declaration of Fundamental Principles and Rights at Work is the most prominent example of the characterization of labour rights as fundamental rights, a characterization that emphasizes their universality and liberates them from analysis solely in economic terms. ${ }^{58}$ The Social Declaration identifies four categories of fundamental rights at work, amongst them freedom of association and the effective recognition of collective bargaining, rights which "go to the essence of human dignity at work, touching upon bedrock values of freedom and equality." ${ }^{9} 9$ The Declaration has what Bob Hepple describes as a "unique legal character." ${ }^{60}$ The obligations are placed on all member states not by reason of ratification of the named conventions, but "... from the fact of membership. This is, therefore, a constitutional obligation not one which rests upon voluntary acceptance." ${ }^{11}$

56 National Union of Public and Government Employees, "Labour Rights" online: NUPGE <http://www.nupge.ca/taxonomy/term/23> (accessed November 25, 2009)

57 See Brian W. Burkett, John D.R. Craig \& Jodi Gallagher, "Canada and the ILO: Freedom of Association since 1982” (2003) 10 C.L.E.L.J. 231; Derek Fudge with John Brewin, Collective Bargaining In Canada: Human Right or Canadian Illusion (Ottawa and Toronto: National Union of Public and Government Employees and United Food and Commercial Workers, 2005) and second edition 2006.

58 International Labour Conference, Declaration on Fundamental Principles and Rights at Work and its Follow-Up, 18 June 1998, 37 I.L.M. 1233, online: International Labour Organization $<$ http://ilo.org/public/english/standards/decla/declaration/text/index.htm> Brian Langille, "The ILO and the New Economy: Recent Development" (1999) 15 International Journal of Labour and Industrial Relations 229 at 241.

59 Anne Trebilcock, "The ILO Declaration on Fundamental Principles and Rights at Work: A New Tool" in Roger Blanpain \& Chris Engels, eds., The ILO and Social Challenges of the 21ST Century: The Geneva Lectures (The Hague: Kluwer, 2001) 105 at 107.

60 Bob Hepple, Labour Laws and Global Trade (Oxford: Hart, 2004) at 59.

61 Ibid. 


\section{CONSTITUTIONALIZING LABOUR RIGHTS}

The second component of the labour rights as human rights strategy is to constitutionalize labour rights, and this can take place at a national or transnational level. This strategy is related to that of pursuing complaints at international institutions in general and the ILO in particular since the goal is to have the jurisprudence of the ILO's supervisory committees recognized as authoritative by constitutional courts. ${ }^{62}$

It is important to contextualize the Supreme Court's change of heart about the nature of labour rights into its political and economic context. By the beginning of the twenty-first century, many governments no longer bothered even to consult with trade unions before changing collective bargaining laws and international institutions had repeatedly criticized Canadian governments for failing to respect labour rights. ${ }^{63}$

The first indication that the Supreme Court was willing to reconsider its labour rights jurisprudence was in 2001, when it held in Dunmore that the Ontario government's failure to include agricultural workers in a legislative scheme supporting collective bargaining impaired their ability to exercise their fundamental freedom to associate. ${ }^{64}$ The majority of the Court made it clear that the freedom of association protected in the Charter has a collective dimension, referring to both Chief Justice Dickson's dissent in the Labour Trilogy and the ILO's jurisprudence as support. ${ }^{65}$ What was remarkable about the decision was that the Court imposed a positive obligation on the government to protect agricultural workers from employers' private power. However, it did so by holding that the

62 For a discussion of the mixed success of this strategy in Europe see Judy Fudge, "Constitutionalizing Labour Rights in Europe" in Tom Campbell, Keith Ewing \& Adam Tomkins, eds., Law and Human Rights Development: Sceptical Essays (Oxford: University Press, forthcoming).

63 Without conducting any public consultation, the Conservative government in Ontario repealed the N.D.P.'s extension of collective bargaining legislation to agricultural workers, which provided final offer selection as a substitute for economic sanctions, Labour Relations Act, 1995, S.O. 1995, c. 1, Sch. A. For a discussion of the legislation see Judy Fudge, "Labour is not a Commodity:' The Supreme Court of Canada and the Freedom of Association" (2004) 67(2) Sask. L. Rev. 425 at 436-7. Similarly, there was no consultation with the unions representing the B.C. health care workers who would be affected by the legislation, despite their express willingness to consult with the government over the issue of health care restructuring. The Minister of Health Services simply telephoned a union representative twenty minutes before Bill 29 was introduced in the legislature to inform the union that the government would be introducing legislation dealing with employment security and other provisions of existing collective agreements. Health Services, supra note 18 at para. 7.

64 Dunmore v. Ontario (Attorney General), [2001] 3 S.C.R. 1016, 207 D.L.R. (4th) 193, 2001 SCC 94 [Dunmore]. I think there are good reasons for the Supreme Court of Canada to provide constitutional protection to key elements of collective bargaining for agricultural workers. I have expressed these opinions in affidavits provided for Dunmore (sworn February 28, 1997 and September 23, 1997) and in support of litigation brought by the United Food and Commercial Workers Union challenging the constitutionality of the Agricultural Employees Protection Act, 2002, S.O. 2002, c. 16 [AEP Act], which was introduced by the Ontario government in response to Dunmore (Michael Fraser v. A.G. Ont, affidavit sworn February 25, 2004 and March $11,2004)$.

65 Ibid. at para. 16 
failure of the Ontario government to include these particularly vulnerable workers within collective bargaining legislation was a signal that it was acceptable to violate their rights. ${ }^{66}$ In effect, the decision constitutionalized a limited range of unfair labour practices in order to preserve the freedom of association.

Dunmore proved to be the thin edge of the wedge for the recognition of labour rights. It marked a change in the "discourse" of the Supreme Court of Canada's interpretation of the Charter in the context of labour rights. However, the majority was careful not to overturn precedent, and the central plank of the Labour Trilogy, that freedom of association did not include collective bargaining, remained strong. ${ }^{67}$

Thus, it was surprising when the Supreme Court held in the Health Services Sector case that "the s. 2(d) guarantee of freedom of association [in the Canadian Charter of Rights and Freedoms] protects the capacity of members of labour unions to engage in collective bargaining on workplace issues." ${ }^{68}$ The Court not only expressly overruled twenty years of jurisprudence that interpreted the freedom of association as excluding collective bargaining, it did so in a case that dealt with collective bargaining in the health-care sector, a politically charged area in which the Court's forays have been extremely controversial. ${ }^{69}$

The decision was an important symbolic and moral victory for the unions representing the non-clinical hospital workers in British Columbia, especially for the thousands of mostly women workers who lost their jobs and saw their wages drop precipitously when their collective agreements were torn up. ${ }^{70}$ The Campbell government's high-handed treatment of these health care workers epitomized governments' cavalier attitude to public sector workers and their unions. As the Supreme Court of Canada emphasized, the British Columbia government introduced Bill 29 without consulting the unions representing the thousands of workers who would be detrimentally affected by the legislation, and it used its majority to pass the legislation in a scant three days. ${ }^{71}$ While the Court was clear that its decision protects the process of collective bargaining, and not the substantive outcomes embodied in collective agreements, the emphasis on the government's duty to bargain in good faith fosters democratic deliberation, at the expense of an instinctive vilification of public sector workers.

According to Chief Justice McLachlin and Mr. Justice LeBel, the authors of

66 Ibid. at paras. 43-48.

67 Ibid. at para. 17

68 Health Services, supra note 18 at para. 2.

69 The Supreme Court has evinced great concern for the fiscal health of Canada's health-care sector, which is essentially a single (government) payer system. In Chaoulli v. Quebec (AG), [2005] 1 S.C.R. 791, the Court opened the door to the privatization of health care by permitting private health insurance in limited circumstances in Quebec. In Newfoundland (Treasury Board) v. NAPE, [2004] 3 S.C.R. 381, the Court accepted the Newfoundland government's fiscal concerns as an acceptable justification to cancel an agreed upon pay equity payment and thereby to violate women's equality rights.

70 See the discussion in Judy Fudge, "Conceptualizing Collective Bargaining under the Charter: The Enduring Problem of Substantive Equality” (2008) 42 Sup. Ct. L. Rev. 213.

71 Ibid:; Judy Fudge, "The Supreme Court of Canada and the Right to Bargain Collectively in Canada and Beyond" (2008) 37(1) Indus. L.J. 25. 
the judgment with which five other members of the Court concurred, ${ }^{72}$

[i]n earlier decisions, the majority view in the Supreme Court of Canada was that the guarantee of freedom of association did not extend to collective bargaining. Dunmore opened the door to reconsideration of that view. We conclude that the grounds advanced in the earlier decisions for the exclusion of collective bargaining from the Charter's protection of freedom of association do not withstand principled scrutiny and should be rejected. ${ }^{73}$

This proposition along with three others - Canada's historic recognition of the importance of collective bargaining to freedom of association, international law's understanding of collective bargaining as an integral component of freedom of association, and the compatibility of a right to collective bargaining with the promotion of other Charter rights, freedoms, and values - were advanced by the majority for the conclusion that s. 2(d) of the Charter protects the process of collective bargaining. These four propositions warrant greater scrutiny, because there is a disconnect between the breadth of the reasons offered by the Supreme Court of Canada for recognizing a constitutional right to bargain collectively and the actual test provided by the Court for determining when such a right has been violated.

In the most astonishing part of the decision, McLachlin C.J, and LeBel J. systematically subject the five reasons provided in the Labour Trilogy and the follow-up decision of Professional Institute of the Public Service of Canada $v$. Northwest Territories (Commissioner) ${ }^{74}$ to critical analysis. They simply dismiss the first reason, that the rights to strike and bargain collectively are "modern rights" created by legislation and not "fundamental freedoms," as "failing to recognize the history of labour relations in Canada," 75 which they develop later in the judgment. They also dispatch the second reason, judicial deference to labour relations policy, as quickly as they did the first, claiming not only that it also ignores history, but that, in addition, it takes "an overbroad view of judicial deference." ${ }^{\prime 6}$ They assert that the third reason, "freedom of association protects only those activities performable by an individual," was overtaken by Dunmore, where the Court recognized that certain collective activities have no individ-

72 Madame Justice Deschamps also agreed that freedom of association included collective bargaining, but she both offered a different test for determining when that right had been violated and provided a different s. 1 analysis of what constituted a lawful infringement of the right. Mr. Justice LeBel is the only member of the Court with a strong background in labour law; in fact, throughout the majority decision reference is made to his co-authored texts on Quebec labour law.

73 Health Services, supra note 18 at para. 22.

74 Supra note 42.

75 Health Services, supra note 18 at para. 25.

76 Ibid. at para 26: "It may well be appropriate for judges to defer to legislatures on policy matters expressed in particular laws. But to declare a judicial 'no go' zone for an entire right on the ground that it may involve the courts in policy matters is to push deference too far. Policy itself should reflect Charter rights and values." 
ual analogue and yet are deserving of protection. ${ }^{77}$ They also reject the fourth reason, suggested by L'Heureux-Dubé J. in PIPSC, that freedom of association was not intended to protect the objects or goals of an association. In so doing, McLachlin C.J. and LeBel J. develop a distinction - between a procedure and its substantive outcome - that is a crucial element in their positive definition of the right to bargain collectively. They claim, in contradistinction to L'HeureuxDubé J., that it will always be possible to characterize the pursuit of a particular activity in concert with others as the "object" of that association. However, they acknowledge that her "underlying concern - that the Charter not be used to protect the substantive outcomes of any and all associations - is a valid one." 78 They declare that "'collective bargaining' as a procedure has always been distinguishable from its final outcomes (e.g., the results of the bargaining process, which may be reflected in a collective agreement)." ${ }^{\text {"T }}$ Thus, they conclude "it is entirely possible to protect the "procedure" known as collective bargaining without mandating constitutional protection for the fruits of that bargaining process." 80

The final and overarching concern that McLachlin C.J. and LeBel J. identify with the majority judgments in the Labour Trilogy and PIPSC is their adoption of a decontexutalized approach to defining the scope of freedom of association, in contrast to the purposive approach taken to other Charter guarantees. The most notorious example of this decontexutalized approach was McIntrye J.'s comparison of trade unions to gun and golf clubs. According to McLachlin C.J. and LeBel J., the main problem with this generic approach is that it ignores the differences between organizations and has "the unfortunate effect" of "overlooking the importance of collective bargaining" - historically and currently - to the exercise of freedom of association in labour relations. ${ }^{81}$

Having made the case for overturning precedent, McLachlin C.J. and LeBel J. resort to history, international law, and Charter values to make the positive case that collective bargaining is protected by the constitutional guarantee of freedom of association. In order to demonstrate that the "protection enshrined in s. 2(d) of the Charter may properly be seen as the culmination of a historical movement towards the recognition of a procedural right to collective bargaining," 82 they review the history of labour relations, beginning with the Middle Ages in England and culminating with the Parliamentary hearings that occurred in 1981 just before the adoption of the Charter. The burden of this review is to show not only that the right to bargain collectively precedes the adoption in the 1940s of Canada's current system of labour relations, but also that the history of Canadian labour law has been a movement from repression to toleration to recognition of collective bargaining, which is described as "the most significant collective activity through which freedom of association is exercised in the labour context." 83

The Court's historical narrative accurately demonstrates that working people

\footnotetext{
77 Ibid. at para. 28.

78 Ibid. at para. 29.

79 Ibid.

80 Ibid.

81 Ibid. at para. 30.

82 Ibid. at para. 68.

83 Ibid. at para. 66.
} 
have long asserted the social practice of collective bargaining as a right and that gradually it was given legal recognition through the enactment of supporting legislation. On a strictly positivist and formalistic approach to W.N. Hohfeld's typology of jural (legal) relations, in which legal rights are regarded as claims rights, it is not accurate to assert that the right to collective bargaining predated collective bargaining legislation. This is because a claims right entails a corresponding legal obligation, and before the introduction of collective bargaining legislation employers were not under a legal obligation to recognize and to bargain with trade unions. ${ }^{84}$ However, if rights are understood as a complex cluster of jural relations - freedoms, rights, powers, immunities, duties, disabilities, and liabilities - that are socially contested, the legal freedom to bargain collectively predates its formal embodiment in legislation that imposed legal obligations upon employers. Jural relations - the precise legal form that a social practice takes - emerge from the dynamic relations between different agents and institutions. ${ }^{85}$

To bolster their case that collective bargaining is an essential element of freedom of association, McLachlin C.J. and LeBel J. resort to international law as an interpretive tool. They identify the International Covenant on Economic, Social and Cultural Rights, ${ }^{86}$ the International Covenant on Civil and Political Rights, ${ }^{87}$ and the International Labour Organization's (ILO's) Convention (No. 87) Concerning Freedom of Association and Protection of the Right to Organize, ${ }^{88}$ each of which Canada has ratified, as important sources for the interpretation of s.2 (d). They go on to note that all of these international documents have been interpreted as including the right to bargain collectively, and they specifically refer to a summary of ILO principles concerning collective bargaining under Convention 98. ${ }^{89}$ Although Canada has not ratified Convention 98, which deals with collective bargaining, Article 2 of the 1998 Declaration of Fundamental Principles and Rights and Freedoms at Work and its follow-up affirms that "all members, even if they have not ratified the Convention in question, have an obligation arising from the very fact of membership in the Organization, to respect, to promote, and to realize, in good faith principles concerning these fundamental rights. ${ }^{90}$ As Adelle Blackett points out, the ILO's supervisory bodies, especially the Committee of Experts on the Application of Conventions and

84 Brian Langille provides a positivist interpretation of legal rights relying on W.N. Hohfeld's typology of jural relations in Fundamental Legal Conceptions as Applied in Legal Reasoning (New Haven: Yale University Press, 1919). Brian Langille, “The Freedom of Association Mess: How We Got into It and How We Can Get out of It” (2009) 54 McGill L.J. 177.

85 For a discussion and application of a dynamic approach to Hohfeld's typology and a criticism of a positivistic approach see Judy Fudge and Eric Tucker, "The Freedom to Strike: A Brief Legal History” (2010) 15 C.L.E.L.J. 533. See also Michael McCann, "On Legal Rights Consciousness: A Challenging Analytical Tradition," in Benjamin Fleury-Steiner and Laura Beth Nielsen, eds., The New Civil Rights Research: A Constitutive Approach (Aldershot: Ashgate Publishing, 2006) at xi.

86993 U.N.T.S. 3 (ICESCR).

87999 U.N.T.S. 171 (ICCPR).

8868 U.N.T.S. 17 (Convention No. 87).

89 Health Services, supra note 18 at para. 77.

90 Adopted 18 June 1998, 37 I.L.M. 123 (ILO Declaration). 
Recommendations and the Committee on Freedom of Association, have offered authoritative guidance on the meaning of freedom of association, including the right to bargain collectively. ${ }^{91}$ Thus, the Court is on firm ground in referring to the observations and commentaries of these supervisory bodies.

Finally, McLachlin C.J. and LeBel J. end their case for interpreting s. 2(d) to include the right to bargain collectively by referring to the Charter's underlying values. Relying on statements made by academic commentators and in Supreme Court judgments about the importance of work and collective bargaining to people's lives, they conclude that "recognizing that workers have the right to bargain collectively as part of their freedom to associate reaffirms the values of dignity, personal autonomy, equality, and democracy." ${ }^{2}$

Having devoted the first half of their decision to the positive case for recognizing a right to bargain collectively, McLachlin C.J. and LeBel J. proceed to explain what this right entails. In light of the judgment's expansive rhetoric extolling collective bargaining as tantamount to a fundamental human right, what is striking is just how limited the right is. Despite the bold statement at the beginning of the judgment "that the s. 2(d) guarantee of freedom of association protects the capacity of members of labour unions to engage in collective bargaining on workplace issues," the actual "right to collective bargaining ....is a limited right." ${ }^{93}$ First, the Charter only applies to state action, that is, to legislation or to the government as an employer. The Charter does not apply to private employers directly. To succeed in arguing that under-inclusive legislation violates freedom of association, a claimant would have to demonstrate "the freedom would be next to impossible to exercise without positively recognizing a right to access a statutory regime." ${ }^{4}$ Second, as the right is to a process; it does not guarantee a certain substantive or economic outcome. Moreover, the right is to a general process of collective bargaining, not to a particular model of labour relations, nor to a specific bargaining method. ${ }^{95}$ Finally, and most importantly, the interference, as Dunmore instructs, must be substantial - so substantial that it interferes not only with the attainment of the union members' objectives (which is not protected), but with the very process that enables them to pursue these objectives by engaging in meaningful negotiations with the employer. ${ }^{96}$ Once the claimant has established that there has been substantial interference, then the onus shifts to the government to demonstrate that the infringement was demonstrably justified under section 1 .

How much protection have workers gained from the constitutionalization of collective bargaining? The answer is not obvious. The Court did not consider modifications to collective bargaining legislation to violate the constitutional guarantee of freedom of association, even changes that meant that workers lost their unions and collective agreements when their work was privatized. Nor is

91 Adelle Blackett, "Mutual Promise: International Labour Law and B.C. Health Services" (2009) 48 Sup. Ct. L. Rev. (2d) 365 at 368-77.

92 Health Services, supra note 18 at para. 86.

93 Ibid. at paras. 2 and 91.

94 Ibid. at para. 34, referring to Dunmore, supra note 64.

95 Ibid. at para. 91.

96 Ibid. at para. 90. 
there a constitutional obligation on the state to protect workers from employers' private power except in very, very limited circumstances. After the decision, the health care workers whose rights were violated received damages of about $\$ 8,000$ each or $\$ 85$ million in total. ${ }^{97}$ However, they lost their unionized jobs and the benefits associated with them, and their wages dropped between 10 and 40 per cent. Moreover, the health care unions had to go through the labourious process of reorganizing the workers who they had previously represented. ${ }^{98}$

The Court has recognized two key features of industrial pluralism - unfair labour practices and a duty to bargain in good faith. It is an open question as to whether the Court can avoid the constitutionalization of the other key elements of industrial pluralism, which are majority-based exclusive representation and dispute resolution mechanisms. Grounding its decision in international law, specifically International Labour Organization and United Nations Conventions that Canada has either ratified or must affirm by virtue of membership, the Supreme Court of Canada has opened the door to these questions. ${ }^{99}$ In this context the s. 1 analysis may play a more prominent role, as it did in the dissenting judgment of Justice Deschamps.

In 2008, in Fraser v. Ontario, the Ontario Court of Appeal began to answer some of these questions and took the next step and constitutionalized the final two features of the industrial pluralist collective bargaining regime. Fraser is the direct successor to Dunmore; it involves a challenge to the exclusion of agricultural workers from collective bargaining legislation. In response to Dunmore, the Conservative government took a minimalist approach to the Supreme Court's decision, and introduced a special Agricultural Employees Protection Act. ${ }^{100}$ This legislation prohibits employers from retaliating against agricultural employees simply for joining or for participating in an employees' association and, in addition, requires the employer to listen to the agricultural workers' representatives. However, it does not impose a duty on the employer to bargain with a workers' representative. The Liberal government, which inherited the Tory legislation, defended its constitutionality.

In Fraser, the Ontario Court of Appeal added the requirements of exclusivity and majoritarianism in the selection of bargaining representatives and a mechanism for resolving negotiating disputes to the definition of freedom of association. Writing for a unanimous court, Chief Justice Winkler stated that

if legislation is to provide for meaningful collective bargaining, it must go further than simply stating the principle and must include provisions that the right be realized. At a minimum, the following statutory protections are required to enable agricultural workers to exercise their right to bar-

97 Vaughn Palmer, "Liberals, health unions reach agreement at point of judicial gun" Vancouver Sun (28 January 2008) A3. The government also enacted legislation to repeal the offending provisions of Bill 29, see Bill $26-2008$ Health Services Amendment Act, $4^{\text {th }}$ Session, 38 ${ }^{\text {th }}$ Parliament, $3^{\text {rd }}$ Reading, May 29, 2008.

98 Fudge, supra note 70 at 242-4.

99 See Fudge, supra note 71 for a discussion of these questions.

100 Agricultural Employees Protection Act, 2002, S.O. 2002, c. 16 [AEP Act]. 
gain collectively in a meaningful way: (1) a statutory duty to bargain in good faith; (2) statutory recognition of the principles of exclusivity and majoritarianism; and (3) a statutory recognition for resolving bargaining impasses and disputes regarding the interpretation or administration of collective agreements. ${ }^{101}$

Whether this decision will stand or not remains to be seen. The Ontario government has appealed it, and the case was argued before the Supreme Court on December 17, 2009. Litigation that began in 1996 in order to bring agricultural workers under collective bargaining legislation continues thirteen years later and agricultural workers in Ontario still do not enjoy the right to bargain collectively.

\section{BRAVE NEW WORDS AND THE ROLE OF THE COURT}

The recognition of collective bargaining as a fundamental right by the $\mathrm{Su}-$ preme Court of Canada invokes brave new words about the significance of collective bargaining to fundamental Canadian values. According to the Court, "[c]ollective bargaining ... enhances the Charter value of equality. One of the fundamental achievements of collective bargaining is to palliate the historical inequality between employers and employees." 102 These words are very important for the legitimacy of labour's collective rights. The failure by many of the architects and apparatchiks of industrial pluralism to appreciate the significance of human rights as a form of opposition to neo-liberalism and as an expression of workers' subjectivity suggests a failure to recognize the significance of both the shift in politics from social democracy to neo-liberalism and the shift in the economy from Fordism to post-Fordism. Constitutional recognition of labour's collective rights is an important recognition of the legitimacy of working people's collective self-organization.

But, however much the Health Services Sector case may signal a brave new world of freedom of association jurisprudence, it does not herald a brave new world of work. The problem is that the Supreme Court appears to have grasped the inner logic and significance of industrial pluralism, like the owl of Minerva, at the moment of its waning.

Industrial pluralism was designed for the post-war economy, and even at its apogee it covered less than half of the working population in Canada. Since the early 1980s, at the very time the Charter was entrenched, this system has proven to be less effective; the wages of unionized workers have stagnated and union density has declined. While it is heartening for people who are concerned

101 Fraserv. Ontario (Attorney General), 2008 ONCA 760, at para. 80. In Travailleurs et travailleuses unis de l'alimentation et du commerce, Section locale 501 v. Johanne L'Écuyer \& Pierre Locas., 2010 QCCRT 0191, the Quebec Labour Relations Board struck down the exclusion of seasonal farm workers from the general regime of union representation that is established by the Quebec Labour Code Code (L.R.Q., c. C-27) as infringing the freedom of association guaranteed by the Canadian and Quebec Charters.

102 Health Services, supra note18 at para. 84. 
with the dignity of workers that the Supreme Court has elevated collective bargaining to a constitutional right, it is unlikely that defensive battles fought in courts can turn the economic and political tide that has undermined the basis for transforming these rights into job security and improved wages for working people. The problem is that the primary institutions of Fordism - the nation state, the large vertically integrated firm, and industrial unions - no longer work because they no longer fit with the dominant forms of governance and prevailing forms of economic organization in a global and networked post-Fordist world. ${ }^{103}$ Industrial pluralism no longer has traction in the private sector, where union density is below 17 per cent. ${ }^{104}$ Moreover, in the public sector, industrial pluralism, which is based upon competitive unionism and competitive labour markets, is not a good match. ${ }^{105}$ For this reason, it is always possible to limit labour rights in the public sector by reference to the broader public interest, and it explains why public sector collective bargaining departs from the pure form of industrial pluralism designed for the private sector.

Constitutionalizing labour rights will not solve the problem of unions' economic and political weakness. Bob Hepple rightly emphasized that the "crucial element in the making of labour laws is power." 106 Since the Health Services Sector decision, unions have launched a raft of challenges, primarily although not exclusively, to public sector legislation that restricts their ability to bargain. ${ }^{107}$ However, these are defensive actions that are designed either to shore up the fading industrial pluralist regime or to perfect it in the public sector.

But the limitations of labour rights strategies that invoke constitutional guarantees do not mean that old forms of workers' struggles on the shop floor and the picket line are the only way forward. This view is simply nostalgia for Fordism's golden past. A smaller, and declining, proportion of workers are employed either in manufacturing or in large workplaces, and workers' identities are less likely, than they ever were before, to be shaped by shop floor or picket line struggles. The forms and content of social and political protest have changed since industrial pluralism was institutionalized in the 1940s. It is important to historicize, and not to fetishize, the past if we are to learn any lessons from it. The crucial question is what social forces are capable of restoring a minimum balance between the economic rights of global capital and the social rights of working people on a domestic and an international level.

It is possible to discern a broader shift in the normative language and institutional arrangements of labour law. Industrial pluralism, with its emphasis on collective bargaining supplemented by grievance arbitration, as the preferred method of standard setting and dispute resolution, is being both eclipsed and colonized by human rights norms. While these norms are important for fostering an inclusive society and a labour market that treats people with equal dignity, the problem is that these norms are only able to flourish if they have in-

103 Fudge, supra note 14.

104 See supra note 9.

105 Judy Fudge \& Harry Glasbeek, “The Legacy of PC 1003” (1995) 3 (3/4) C.L.E.L.J. 357.

106 Hepple, supra note 60 at 257. [emphasis in original]

107 See Fudge, supra note 70 at 214-5. 
stitutional support. It is important to heed the words of the political economist Karl Polanyi, who in 1944 wrote: "No mere declaration of rights can suffice; institutions are required to make the rights effective." 108 The key challenge for people who support working peoples' rights is to identify and to promote organic and sustainable institutions that can serve as platforms for rights at work.

However, the need for a plurality of workers' democratic and autonomous self-organizations that reflect the heterogeneity of workers and their employment relations does not mean that the state does not have a positive role to play. Freedom of association cannot flourish in the world of work if the state takes an agnostic stance to employers' exercise of private power. As Bob Hepple and Gillian Morris have argued,

$[\mathrm{t}]$ he assignment, interpretation, and protection of property rights of the owners of a business are not cost-free but are delivered at a cost to taxpayers, workers, and consumers. Employment rights are part of an ancillary exchange by which governments and employers recompense or give recognition to workers for the inequality of outcomes in the employment relationship. ${ }^{109}$

Negative liberties alone will not suffice to protect labour rights; the state must impose correlative duties on employers to recognize workers' autonomous and democratic representatives. Unions have always needed and will continue to need state power to restrict the possessive individualism of the common law and to protect workers' freedom to collective self-determination from market authoritarianism. Positive rights, not simply negative liberties, are necessary to democratize the world of work.

What is the appropriate role of the Supreme Court of Canada when it comes to interpreting the Charter in the context of labour rights? It is important to connect the values enshrined in the Charter to the specific context of labour relations in liberal capitalist democracies. The claim that in the Health Services Sector judgment the Supreme Court of Canada Court adopted "an approach that is exclusively contextual" and, thus, one that "compromises the fundamentals of constitutional interpretation," 110 misconceives both the basis for, and benefits of, a contextual approach. The assertion that a contextual methodology that traces the pedigree of entitlements is "quixotic"111 demonstrates a lack of knowledge of historical methodologies and historical claims as well as a lack of appreciation for the essential role of context in giving meaning to Charter values.

Discussing the Court's reasoning in the Health Services Sector case, Jamie

108 Karl Polanyi, The Great Transformation: The Political and Economic Origins of Our Time (Boston: Beacon Press, 1957) at 276.

109 Bob Hepple, "Rights at Work" in Dharam Ghai, ed., Decent work: Objectives and Strategies (Geneva: ILO and IILS, 2006) 53 quoting Bob Hepple and Gillian Morris, "The Employment Act 2002 and the Crisis of Individual Employment Rights” (2002) Indus. L.J. 245 at 249.

110 Jamie Cameron, "Due Process, Collective Bargaining, and s.2(d) of the Charter: A comment on B.C. Health Services” (2006-7) 13 C.L.E.L.J. 323 at 347.

111 Ibid. at 340 . 
Cameron states:

whether collective bargaining is protected turned on the Court's reading of history, which could have supported any number of interpretations. In principle, the use of history to validate the constitutional status of an entitlement sets a dangerous precedent. Not only is the interpretation of history a notoriously subjective project, it is one that ordinarily will not generate progressive insights into the scope of entitlement. ${ }^{12}$

In contrast to the limitations of an historical and contextual approach, which she appears to equate with an originalist approach, Cameron asserts the benefits of an abstract approach. However, she fails to explain how a contextual and historical approach, which is constrained by the requirements of evidence and widely accepted canons of interpretation, is more subjective and less determinate than abstract reasoning. Abstract reasoning from principles can result in incommensurable articulations of values, formal versus substantive equality being the most obvious example. The assertion that a contextual approach to interpreting Charter rights and freedoms inevitably results in a narrow approach simply does not hold water. In fact, it was Justice McIntryre's abstract approach to interpreting the freedom of association that led him to make the claim, which Cameron criticizes, ${ }^{113}$ that s. $2(\mathrm{~d})$ only protects associational activities in which an individual could lawfully engage. Whether a contextual approach narrows or expands a particular right depends both upon the context in which the right is invoked and the values that Court identifies as underlying and informing the right.

In contrast to a contextual and historical approach, Cameron endorses an abstract approach to attributing meaning to the freedom of association that draws on its underlying values. However, although she discusses the prior jurisprudence, she never identifies what those values are. ${ }^{114}$ The meaning of the rights enshrined in the Charter, like the values - democracy, personal autonomy, and dignity - the Charter is designed to promote, are essentially contested. ${ }^{115}$ There is no royal road that leads to answers to these questions; the meaning of Charter

112 Ibid. at 348-349. I would like to thank Colleen Sheppard for bringing the comparison with U.S. constitutional jurisprudence to my attention.

113 Ibid.

114 Ibid. at 353-9. She refers to Bastarache J.'s judgment in Dunmore and she praises Chief Justice Dickson's approach in the Trilogy as illustrating the value of an abstract approach, and confirming that an interpretation that defines a guarantee's underlying purposes need not preclude attention to context. However, as Dianne Pothier pointed out, although Dickson C.J. made it clear that not all associational activity attracts constitutional protection merely because it is engaged in by more than one person, "he never clearly articulated what it was about the objects of unions that would determine what kinds of objects of other associations would merit constitutional protection." Dianne Pothier, "Twenty Years of Labour Law and the Charter" (2002) 40 Osgoode Hall L.J. 369 at 379 [footnote omitted].

115 In her discussion of the Labour Trilogy, Cameron implicitly acknowledges that judges have different conceptions of the values that give meaning to freedom of association, supra note 110 at $355-7$. 
rights is not revealed, but rather, constructed in an historical context through a process of public discussion and social contestation.

Judgments that recognize the scope of legitimate disagreement over the meaning of Charter rights and values, and how this disagreement has evolved in a specific context, have the advantage of transparency. By identifying the choices that it must make and providing reasons, which are based in principle and in a social context, the Court is accountable for its choices. Judicial accountability is a core value in legal and political systems that provide a central role for judicial review. Law, alone, does provide principled reasons for any specific choice. Values like democracy, equality, and dignity have a range of different meanings, and it is incumbent on courts to provide reasons for preferring one interpretation to another. Moreover, these reasons must connect to the context in which the right is invoked.

In Health Services Sector, the Supreme Court of Canada identified human dignity, equality, liberty, respect for the autonomy of the person, and the enhancement of democracy as among the values that underlie the Charter. ${ }^{116}$ Moreover, citing case law and referring to academic commentary, the Court asserted: "all of these values are complemented and, indeed, promoted by the protection of collective bargaining in s. 2(d) of the Charter. ${ }^{117}$ Thus, the Court began to link the context of labour relations to the broader values that the Charter is designed to promote and to protect. However, the Court will need to develop and to elaborate these linkages when deciding the cases that will inevitably come before it.

"Freedom of organisation," Otto Kahn-Freund wrote, "has two social and therefore two legal functions. It is a civil liberty, a human right, an aspect of freedom of association ... [I]ts existence and adequate guarantees for its exercise, are, however, also indispensable conditions for the operation of collective labour relations." ${ }^{118}$ It is the dual function of the freedom of association that requires particular attention. It is important for courts to interpret the freedom of association in a manner that promotes a democratic space for trade unions and to maintain, to protect, and to extend legislative support for their core functions, which are expressing and representing working people's interests in the world of work and collective bargaining. Governments that use their political mandate to revoke collective agreements and to repeal collective bargaining legislation without providing an opportunity for consultation and public debate ought to be reined in by courts in order to protect the democratic values of public discussion and public accountability. Moreover, governments that refuse to provide workers who are employed in occupations and industries that have historically been excluded from collective bargaining rights to which the majority of Canadian workers are entitled should be held to account for their exclusion. As Blackett has put it, the Court's "role is to ensure that the constitutionally protected fundamental principles and rights at work are respected, and in this man-

116 Health Services, supra note 18 at para. 81.

117 Ibid.

118 Cited in Lord Wedderburn, "Freedom of Association or Right to Organise? The Common Law and International Sources" in Lord Wedderburn, ed., Employment Rights in Britain and Europe (London: Lawrence and Wishart, 1991) 142. 
ner they may reserve a semi-autonomous space critical to pluralist labour law's survival." 119

But do these reasons for providing constitutional protection for collective bargaining entail that the protection should only extend to procedural rights? As commentary on the duty to bargain in good faith has demonstrated, it is impossible to separate completely process from substance. ${ }^{120}$ The Court considers it legitimate to look at the norms of an industry to provide an objective standard for determining whether an employer is making all reasonable efforts to bargain in good faith. ${ }^{121}$ It is important for the Court to continue to recognize that the boundary between procedural and substantive rights is permeable, and thus it must be attentive to situations in which governments may undermine the collective bargaining process either by imposing substantive terms on workers and their unions or excluding certain terms from the bargaining process. ${ }^{122}$

Should the right to bargain collectively be characterized as an individual or a collective right? In answering this question it is important to distinguish between the question of who possesses the right (the individual or the collective) and the question of the conditions necessary for the right's successful exercise. ${ }^{123}$ Collective bargaining could be viewed as an individual right, in the sense that it vests in the individual worker and not in the collective, which is the trade union. But, even if it were to be considered an individual right, collective bargaining would be one of a hybrid nature, since it is a right that can only be enjoyed by individuals when it is exercised collectively. ${ }^{124}$ In this conception of the right to bargain collectively the individual possesses the right, but the right is collective to the extent that it can only be exercised in concert with others. It recognizes that the right vests in the individual; however, it also appreciates the qualitative difference between individual and collective bargaining. ${ }^{125}$ Collective bargaining, unlike individual bargaining, is essentially an associational activity. ${ }^{126}$ Thus, the analogy that Brian Langille, following Justice McIntyre, makes between the individual right to contract and the right to bargain collectively misses the distinctive feature of collective bargaining, that it is an exercise in solidarity in which individual interests are not simply aggregated but transformed in the process of democratic deliberation. ${ }^{127}$ Once the distinctive feature of collective

119 Blackett, supra note 91 at 386-7.

120 See also Cameron, supra note 110 at 336-341

121 Royal Oak Mines Inc. v. Canada (Labour Relations Board), [1996] 1 S.C.R., at para. 42.

122 Brian L. Langille \& Patrick Macklem “Beyond Belief: Labour Law's Duty to Bargain” (1988) 13 Queen's L.J. 62.

123 Sheldon Leader, Freedom of Association: A Study in Labor Law and Political Theory (New Haven: Yale University Press, 1992) at 35.

124 Ibid. at 32 .

125 Langille, supra note 84 at 188 , claims that collective bargaining has an obvious individualbargaining analogue and his accusation that the Court makes "the mistake of taking tautologies as having analytic import" fails, as I argue below, to engage with alternative conceptions of the right to bargain collectively as a hybrid individual-collective right or as a collective right, despite the fact that he cites Sheldon Leader, ibid., who discusses in detail these distinctions.

126 Dunmore, supra note 64 at para.13, quoting Alberta Reference, supra note 17 at 367.

127 Alan Bogg, The Democratic Aspects of Trade Union Recognition (Oxford and Portland: Hart Publishing, 2009) at 245-8; Mark Barenberg, "Democracy and Domination in the Law of 
bargaining is recognized it is easy to dismiss Robert Charney's fear that constitutionalizing a right to bargain collectively entails adopting a "contract clause" in Canada such that an individual right to contract will also receive constitutional protection. ${ }^{128}$ The shift from the collective to the individual level is based on the contentious assumption that what is crucial about collective bargaining is the process of making a bilateral contract rather than the process of people coming together in solidarity to determine collectively how to put forth a common platform regarding the governance of their working lives. Collective bargaining can be conceived as a form of democratic deliberation and not simply a process of interest aggregation. ${ }^{129}$

But, it is also possible to conceive of the right to bargain collectively as a collective right in the sense that the right is vested in the collective (the union), and not in individual employees. While the problem with this approach is that it begs the deeper normative question concerning the needs and priorities of collectivities such as trade unions that ought to be constitutionally protected, conceptualizing collective bargaining as a collective right is neither, as Langille claims, tautological nor incoherent. ${ }^{130}$ Conceptualizing collective bargaining as a collective right that vests in the union is coherent - in fact, it is compatible with the Wagner model of majoritarian-based exclusive bargaining rights. The reason for objecting to it is consequential.

Whether the right to bargain collectively is considered to be a hybrid-individual right that can only be exercised collectively or a purely collective right has important consequences. ${ }^{131}$ A right to bargain collectively that vests in the individual would not depend upon the existence of an acceptable or officially recognized trade union. Even if the right were to vest in the individual, it would not necessarily follow that when the individual's right clashes with the collective that the individual's right would take precedence. How to resolve any conflict between the individual and the collective would depend on the rights and interests at stake and how they are exercised. However, if the right to bargain collectively is seen as vesting in the collective as an institution, then the individual would not have the right to engage in collective pursuits outside of what he or she engages in through that institution. Moreover, vesting the right to bargain collectively in the collective would require some prior notion of, and justification for, the "acceptable" objects of unions. The problem with such an approach to the freedom to associate is that it precludes a range of alternative collectivities through which individuals can operate. ${ }^{132}$ In effect, what it does is elevate the

Workplace Cooperation: From Bureaucratic to Flexible Production” (1994) 94 Colum. L. Rev. 736 at 796.

128 Robert E. Charney, “The Contract Clause Comes to Canada: The British Columbia Health Services Case and the Sanctity of Collective Agreements" (2007/2008) 23 N.J.C.L. 65.

129 Bogg, supra note 127 at 219; Barenberg, supra note at 127.

130 Langille, supra note 84 at 183-6.

131 As Leader demonstrates, these consequences are much more important when it comes to the right to strike, and he illustrates these consequences by contrasting the case of France, where the right to strike is an individual right that vests in the workers, with that of Germany, where the right is a collective one that vests in the union: see supra note 123 at 183-200.

$132 \mathrm{Ibid}$. at 205. 
tenets of a particular form of industrial pluralism, in which trade unions have exclusive bargaining rights, to a constitutional right.

In Health Services Sector, the Supreme Court stated that its goal was not to constitutionalize any specific labour relations framework. ${ }^{133}$ Has the Ontario Court of Appeal constitutionalized the Wagner-style collective bargaining regime in its decision in Fraser, and, if so, was it legitimate for it to do so? The industrial pluralist model of collective bargaining, as Blackett reminds us, "remains important for significant proportions of the working population, and for the ongoing viability of trade unions and collective bargaining mechanisms in many sectors, notably the public sector and para-public sectors like health care and education." ${ }^{134}$ This model is the way that freedom of association and collective bargaining have been institutionalized in Canada. That this model has limited application to the new "Wal-Mart" economy is beyond question. ${ }^{135}$ Thus, it fails to provide effective collective bargaining to an increasing proportion of working people in Canada. However, there is no contradiction for the Supreme Court to recognize that industrial pluralism is the preferred model of collective bargaining legislation in Canada and, thus, that it should be extended to working people who cannot otherwise achieve effective collective bargaining, and to provide governments with the freedom to develop other models of collective bargaining that are effective in protecting the dignity and autonomy of working people and furthering democracy and equality in the world of work. ${ }^{136}$

\section{CONCLUSION: THE CUNNING OF HISTORY}

I want to conclude by considering the paradoxes that are embedded in the project of constitutionalizing labour rights. Paradoxes conflict with preconceived notions of what was reasonable or possible. After the Labour Trilogy in 1987, it did not seem possible that the Supreme Court of Canada would recognize the right to collective bargaining as fundamental.

According to the political theorist Wendy Brown, a paradox is not an impossible political condition, but it is a demanding and frequently unsatisfying one. ${ }^{137}$ This description captures the tension in the project of constitutionalizing labour rights. Law is replacing politics as the vehicle for articulating needs, interests, and rights in the public sphere. Neo-liberalism is not only about constructing markets; it is also about restructuring political power. It involves a

133 Health Services, supra note 18 at para. 91.

134 Blackett, supra note 91 at 396, footnote omitted.

135 Ibid.; Judy Fudge, "The Gendered Dimension of Labour Law: Why Women Need Inclusive Unionism and Broader-Based Bargaining" in Linda Briskin \& Patricia McDermott, eds., Women Challenging Unions (Toronto: University of Toronto Press, 1993) 321; Judy Fudge, "Feminization and Fragmentation: The Challenge of Equity for Labour Market Policy," in Janine Brodie, ed., Women and Public Policy in Canada (Toronto: HBJ, 1995) 57; Cynthia Cranford, Judy Fudge, Eric Tucker, \& Leah Vosko, Self-Employed Workers Organize: Law, Policy, and Unions (Montreal-Kingston: McGill-Queen's Press, 2005).

136 Blackett introduces the idea of a comparative labour law methodology that would enable the court to assess functional equivalents to collective bargaining rather than constitutionalize a particular model. Supra note 91 at 394-403.

137 Wendy Brown, States of Injury (Princeton: Princeton University Press, 1995) at 430. 
shift from parliamentary to judicial and executive power. Alain Supiot claims "juridical devices specific to democracy, whether electoral freedoms or freedom of association, make it possible to process the stuff of political and social unrest and to convert tests of strength into test cases." ${ }^{138}$ Thus, constitutionalization can be seen as reinforcing some of the institutional aspects of neo-liberalism, such as the increased role of the courts.

But this shift in political power is not inevitable. Rights are not won by legal arguments alone; rights involve political visions, institutions, and strategies. The rise of rights discourse under neo-liberalism also presents opportunities as well as perils. Paradox also signifies a doctrine of openness that challenges received authority, goes against the doxa. ${ }^{139}$ Perhaps, the constitutionalization of labour rights provides an opportunity to envision an entirely different conception of rights to which we must appeal. The dynamics of social solidarity are different from those of neo-liberalism, and the latter's orientation to market forces. The promise of constitutionalizating labour rights is that it will help to restore the balance of power by shifting it away from capital and more to labour and in this way preserve the social world from the rapaciousness of the market.

As neo-liberalism is discredited by the current economic crisis, political struggles over how rights get represented, articulated, and eventually institutionalized move to centre stage. ${ }^{140}$ As a student of legal history, I am not confident that the courts have the capacity to appreciate the role that trade unions and labour law play in cultivating fundamental values like dignity, equality, and democracy. My fears were confirmed in a 2009 decision by the Supreme Court of Canada, in which Justice Binnie took a narrow and formalistic approach to a case involving the legality of Wal-Mart's closure of its first unionized store in Quebec after a union's successful organizing drive. In justifying this approach, Justice Binnie noted that the right to collective bargaining recognized in the Canadian constitution is a narrow right, commenting:

Care must be taken not only to avoid upsetting the balance the legislature has struck in the Code taken as a whole, but not to hand to one side (labour) a lopsided advantage because employees bargain through their union (and can thereby invoke freedom of association) whereas employers, for the most part, bargain individually. ${ }^{141}$

These remarks indicate little appreciation of the fact that in the instant case

138 Alain Supiot, "Viking-Laval-Rüffert: Economic Freedoms versus Fundamental Social Rights - Where Does the Balance Lie?” European Trade Union Institute (ETUI-REHS) online: http:// www.etui.org/en/content/search?SearchText=supiot at 4-5, The original version of this article, in French, was published in the "Revue Permanente du Mauss," online:<www.journaldumauss. net/spip.php?article283>.

139 Brown, supra note 137 at 431.

140 Margaret R. Somers \& Christopher N.J. Roberts, "Toward a New Sociology of Rights: A Genealogy of 'Buried Bodies' of Citizenship and Human Rights” (2008) 4 Annual Review of Law Social Sciences 385 at 407

$141 \mathrm{Ibid}$. at para. 57. 
Wal-Mart is the world's largest public corporation by revenue and, with 2.1 million employees worldwide, the largest private employer in the US and Mexico, and one of the largest in Canada. Justice Binnie's remarks also suggest a concern, long held by common law courts, to ensure a balance in which freedom of association does not interfere too greatly with the norm of individual contracting. However, as a student of labour history, I am hopeful, even in these bleak times, that working people will continue to assert their rights to bargain collectively and to strike, and that the Supreme Court will come to recognize, as did Justice Rand, that collective labour rights are an important part of the "balance of what is called social justice." ${ }^{142}$ 